УДК 349.6

DOI https://doi.org/10.32837/pyuv.v0i2(27).193

3. В. Яремак

кандидат юридичних наук, доцент,

доцент кафедри трудового, екологічного та аграрного права

Прикарпатського національного університету імені Василя Стефаника

\title{
СОЦІАЛЬНА ПРИРОДА ЕКОЛОГО-ПРАВОВОГО КОНФЛІКТУ
}

Постійне зростання конфліктності еколого-правових відносин, необхідність удосконалення екологічного законодавства та приведення його у відповідність до міжнародних стандартів охорони довкілля зумовлюють актуальність дослідження еколого-правових конфліктів в Україні. Питання екологічних конфліктів сьогодні вимагають концентрації уваги на пошуках шляхів ïx врегулювання і максимального зосередження на екологічній проблемі зі сторони всіх галузей знань. Адже, як слушно зауважує Н.Р. Кобецька, правове оформлення оптимального поєднання економічних, споживацьких інтересів у задоволенні ресурсних потреб економіки та екологічних інтересів, спрямованих на забезпечення життєво необхідної потреби існування в безпечному, ресурсно та екологічно збалансованому довкіллі, передбачає потребу використання міжгалузевого інструментарію в регулюванні досліджуваних відносин [1, с. 40].

Метою публікації є детальний аналіз особливостей конфлікту із визначенням його соціальної природи та на основі цього проведення дослідження екологічного конфлікту як різновиду соціально-правового. Комплексний аналіз змістовних соціальних характеристик екологічного конфлікту надалі дасть змогу визначити максимально ефективні шляхи його врегулювання та мінімізувати негативні наслідки і має не тільки актуальне, але й концептуальне значення для теорії та практики екологічного права.

Екологічні конфлікти є предметом дослідження багатьох суспільних наук, кожна з яких визначає та характеризує даний вид конфлікту 3 позицій предмету окремої галузі знань. Серед усіх соціальних конфліктів, як на глобальному, так і на регіональному та локальному рівнях, екологічні конфлікти є чи не найменш дослідженими. Саме тому питання конфліктної взаємодії суспільства i природи досліджують багато науковців. Серед правників проблемами суспільної конфліктності займаються С.В. Бобровник, В.М. Крівцова, В.М. Кудрявцев, М.М. Олексюк, С.Ф. Орлов та ряд інших. 3 позицій соціології дослідженням екологічного конфлікту займалися В.М. Василенко, О.В. Келасьєв, Н.М. Миліна.

Поліфункціональність категорії конфлікту як основоположного поняття для екологічного конфлікту зумовлюе складність визначення поняття та неоднозначне розуміння його сутнісних характеристик. Спеціальна галузь знань, об'єктом вивчення якої є суспільство, але у так званому нестабільному стані - «соціум конфліктний» $[2$, с. 5] - конфліктологія, визначає конфлікт як «зіткнення інтересів, потреб і спричиненої цим зіткненням боротьби сторін» [3, с. 26-27], які за своєю суттю є специфічними соціальними взаємодіями, що характеризуються переважно протиставленням, а не співробітництвом, із невизначеним колом суб'єктів, сторін, кожна із яких має самостійні інтереси, за визнання яких і бореться [4, с. 121].

У дослідженнях С.В. Бобровник, яку вважають одним із провідних фахівців вітчизняної юридичної конфліктології, на основі антрополого-комунікативного підходу до питань конфлікту останній трактується як «стан двостороннього зв'язку суб'єктів, заснований на правовому протиріччі, що характеризується порушенням або перешкодою в реалізації ними інтересів та слугує причиною розвитку або кризи суспільних відносин» $[5$, с. 6].

Звужуючи коло наукового пошуку до правового конфлікту як окремого виду конфлікту соціального, вчені також розкривають його зміст, вказуючи на суперечності соціальної взаємодії: юридичний конфлікт визначається як протиборство двох чи кількох суб'єктів, зумовлене протилежністю чи несумісністю їх інтересів, потреб або цінностей [6]; як протистояння сторін з різними інтересами, що має юридичний характер або має хоча б один елемент юридичного характеру, але обов'язково завершується (або здатне завершитись) юридичним способом [7, с. 432-433]; юридичний конфлікт - найбільш цивілізована форма соціального протиборства, яке здійснюється в межах певної правової процедури [8, с. 8].

Водночас аналіз правового конфлікту крізь призму соціального конфлікту піддається критиці, обгрунтовуючи це тим, що вивчення юридичного конфлікту та визначення його поняття засноване на наявних положеннях теорії соціального конфлікту, і тільки потім виявляються його особливі правові чи юридичні характеристики. Як наголошується у наукових дослідженнях, багато що в природі та суті соціального і юридичного конфлікту є схожим і однорідним, однак 
не можна забувати перш за все про специфічну сферу існування і прояву юридичного конфлікту - правову [9, с. 143]. Безперечно, розгляд та дослідження явища юридичного конфлікту по аналогії із соціальним має ряд позитивних моментів, адже соціальний складник характерний для внутрішньої стадії розвитку юридичного спору (протиріччя) та дозволяє вивчати правовий конфлікт з точки зору його «психологічності», соціальності, однак, як звертає увагу В.М. Кудрявцев, «будь-який юридичний конфлікт є соціальним, однак не всі соціальні конфлікти є юридичними» $[10$, с. 5]. Отже, пропонується відійти від усталеного підходу до визначення юридичного конфлікту по аналогії із соціальним та досліджувати природу юридичного конфлікту винятково з позицій теорії права.

Однак категорично заперечувати соціальний змістовний складник конфлікту юридичного не варто, адже, як слушно зауважує С.В. Бобровник, визначення базової категорії, яка здатна бути основою дефініції правового конфлікту, має грунтуватися на сутнісних характеристиках зазначеного явища, а саме: це специфічний стан суспільних відносин, особливостями якого є наявність соціальних протиріч між учасниками конфліктних відносин [11, с. 180], тобто йдеться про соціальний характер правового конфлікту. На підставі цього автор поряд із правовими ознаками виокремлює ті особливості, які визначають соціальну сутність юридичного конфлікту:

1) конфлікт порушує або перешкоджає суб'єктам реалізовувати свої інтереси;

2) конфлікт завжди має двосторонній характер, який зазвичай характеризується асиметрією суб'єктів, наявністю домінуючої та підпорядкованої сторони;

3) передумовою виникнення конфлікту є соціальні протиріччя (порушення заборон, невиконання зобов'язань, зловживання правами, відсутність взаємоповаги до іншої сторони, недобросовісна конкуренція тощо);

4) залежно від походження (еволюційна та радикальна концепція конфлікту) та змістовно-функціональних особливостей конфлікт може сприяти стабілізації суспільства, розвитку нових суспільних відносин або призводити до дестабілізації, деструкції;

5) конфлікт є процесом, що має суб'єктивно-об'єктивний характер, де суб'єктивним складником є поведінка суб'єктів, а об'єктивним - соціальні протиріччя [11, с. 180-181].

Заперечення та абстрагування конфлікту юридичного від соціального апріорі неможливо у зв'язку з тим, що правовому конфлікту притаманний соціальний характер, а суспільні відносини, отримуючи правову регламентацію, набувають форм конфлікту юридичного. У юридичній науці для позначення цього явища застосовується термін юридизація - процедура надання явищам соціальної дійсності правового характеру [12]. Білоруські вчені вважають, що процедура юридизації може зводитися до правотворчого процесу, коли певні суспільні відносини підлягають правовому регулюванню, отримують свою формалізацію і чітке визначення суб'єкта, об'єкта, а також суб'єктивних прав і юридичних обов'язків. При цьому фактичний зміст таких суспільних відносин в результаті юридизації практично не змінюється, однак їх форма істотно перетворюється. Юридизація також може бути під час здійснення правореалізаційної діяльності, особливо у процесі правозастосовної практики. В такому разі доцільно говорити про юридизацію соціальних конфліктів, які виходять за межі міжособистісного спілкування і набувають специфічних ознак, елементів та способів вирішення [13, с. 286]. Аналогічної думки дотримується і вітчизняний науковець В.M. Крівцова: «Перетворення неюридичного конфлікту на правовий можливо лише шляхом юридизації - специфічної інституціоналізації конфліктних відносин» [8, с. 7].

Iз зазначеного вище робимо висновок про те, що правовий конфлікт необхідно досліджувати на основі нерозривної єдності її соціальної основи із правовим змістом. Родові ознаки соціального конфлікту у конфлікті юридичному трансформуються у ознаки правового характеру та набувають юридичного «звучання» .

На підставі запропонованого уніфікованого підходу до розуміння сутнісних характеристик конфлікту проведемо дослідження екологічного конфлікту та його ідентифікацію як специфічного соціально-правового явища - еколого-правового конфлікту.

З метою подальшої ідентифікації категорії екологічного конфлікту зупинимося на особливостях цього виду протиріччя, які сприяють виокремленню (виділенню) екологічного конфлікту серед однопорядкових категорій. Так, О.В. Келасьєв, досліджуючи екологічні конфлікти 3 позицій соціології, виокремлює такі характерні ознаки:

1) предмет соціально-екологічного конфлікту виокремлює його зі всього класу соціальних конфліктів, оскільки ним завжди є деяка проблема у сфері взаємодії суб'єктів з природою, яка передбачає дії, що можуть призвести до змін в соціоприродній системі;

2) об'єктом соціально-екологічного конфлікту можуть бути: а) природні об'єкти; б) техногенні системи та об'єкти, що впливають на природне середовище; в) засоби контролю над природними і техногенними об'єктами тощо;

3) ці конфлікти мають екзистенціальний характер, оскільки стосуються фундаментальних проблем життя та існування людей; 
4) наслідки екологічних конфліктів досить часто мають невідворотний характер, на відміну від інших соціальних конфліктів;

5) географічні кордони, а також потенційний склад учасників, яких торкається конфлікт, часто невизначені [14, с. 27-28].

B.M. Василенко наголошує на важливості для екологічних конфліктів соціально-психологічного фону й атмосфери в суспільстві, а їх урегулювання можливе на основі та шляхом екологічної самоідентифікації всіх суспільних інститутів, економічних та інших структур соціуму і соціалізації екологічних наук [15, с. 75]. Н.М. Миліна визначає особливості структури екологічного конфлікту, яка, на ї̈ думку, є складною системою взаємопов'язаних елементів, як соціальних, так і екологічних, у зв'язку з чим екологічні конфлікти визначаються як комплексні [16, с. 260].

Російська вчена у галузі екологічного права О.Л. Дубовік, розглядаючи екологічний конфлікт, виокремлює його специфічні риси, роблячи акцент на соціальному складнику, а саме: (a) іманентність (внутрішня приналежність) суспільству (спричинені взаємодією суспільства i природи екологічні конфлікти відображають зміст процесів життя людей в наявних природних умовах; взаємодія суспільства і природи відбувається на принципово обмеженій основі і пов'язана 3 витрачанням об'єктивно обмежених, важко відновлюваних або взагалі невідновлюваних ресурсів); (б) соціальність екологічних конфліктів, їх суспільна природа та значимість (будь-яка екологічна втрата одного учасника є втратою і всіх інших, тобто неможливо завдати шкоди навколишньому середовищу так, щоб не зачіпати інтересів третіх осіб); (в) гносеологічні труднощі щодо їх вирішення (знання людей у сфері взаємодії з природою є недостатніми, а тому необхідно досить обережно ставитися до можливостей мислення людини, науки, а відповідно, й до державного регулювання екологічних конфліктів правовими засобами) [17, с. 7-8].

Соціологічне дослідження екологічної конфліктності створює передумови для юридичного аналізу цієї категорії. Навіть більше, як наголошує О.Л. Дубовік, таке дослідження передбачає оснований на емпіричній інформації соціологів і екологів аналіз факторів і видів конфліктів, який «найбезпосереднішим чином визначаєпотребуеколого-правового регулювання, його цілі, вектор, використовувану юридичну техніку тощо» [4, с. 121].

Як висновок доцільно зазначити наступне. На нашу думку, екологічний конфлікт необхідно розглядати винятково як соціальне протиріччя, що протікає в особливих умовах - природному середовищі існування людини. Досліджуючи проблематику екологічних конфліктів, нами обгрунтовується необхідність його вивчення на основі дедуктивного аналізу шляхом вивчення загального поняття конфлікту як соціального явища, конкретизації соціально-правового конфлікту та деталізації у сфері правового регулювання - еколого-правового конфлікту. При цьому слід брати до уваги ті властивості, які характеризують еколого-правовий конфлікт з позицій соціальних зв'язків. Так, предмет, об'єкт, структура, наслідки, форми врегулювання еколого-правового конфлікту як базові характеристики соціальноекологічного конфлікту розглядатимуться та аналізуватимуться з позицій права, надаючи їм юридичного характеру та змісту, що і стане предметом нашої подальшої наукової розвідки.

\section{Jimepamypa}

1. Кобецька Н.Р. Правовий режим використання природних ресурсів: поняття, особливості. Екологічне право України. 2016. № 3-4. С. 37-43.

2. Конфліктологія : навч. посіб. / Л.М. Герасіна, М.П. Требін, В.Д. Воднік та ін. Харків : Право, $2012.128 \mathrm{c}$.

3. Іванов В.М., Іванова О.В. Юридична конфліктологія : навч. посіб. для студ. вищ. навч. закл. Кийв : МАУП, 2004. $224 \mathrm{c}$.

4. Дубовик О.Л. Экологическое право и экологические конфликты. Право и политика. 2006. № 5. C. $116-136$.

5. Бобровник С.В. Компроміс і конфлікт у праві: теоретико-методологічне дослідження : автореф. дис. ... д-ра юрид. наук. Київ, 2013.

6. Шемшученко Ю.С. Юридична енциклопедія : в 6 т. / редкол.: Ю.С. Шемшученко (відп. ред.) та ін. Київ : Укренцикл., 1998. Т. 3: К - М. 792 с.

7. Общая теория государства и права. Академический курс : в 3 т. / отв. ред. проф. М.Н. Марченко. Москва : Зерцало-М, 2002. Т. 3.528 с.

8. Крівцова В.М. Юридичний конфлікт як феномен правової дійсності : автореф. дис. ... канд. юрид. Наук. Харків, 2005. 20 c.

9. Арабаджиева О.В., Гомонов Н.Д. Юридический конфликт: природа и особенности. Вестник МГТУ. Москва. 2006. Том 9. №1. С. 142-147.

10. Юридическая конфликтология. / под ред. В.Н. Кудрявцева. Москва. 1997. 306 с.

11. Бобровник С.В. Компроміс і конфлікт у праві: антрополого-комунікативний підхід до аналізу : монографія. Київ, 2011. 383 с.

12. Большой юридический словарь / упорядк. А.Я. Сухарев, В.Е. Крутских. Москва : Инфра-М. 2003.

13. Белорусская юридическая энциклопедия. В. 4 т. / редкол. : С.А. Балашенко [и др.]. Минск : ГИУСТ БГУ, 2013. T. 4. T-Я. C. 286.

16. Мылина Н.Н. Теоретико-методологические основы исследования экологических конфликтов как социальной категории. Историческая и соииальнообразовательная мысль. 2014. № 6-2. С. 258-261.

14. Келасьев О.В. Социально-экологические конфликты и технологии их разрешения : дисс. ... кандидата социологических наук. Санкт-Петербург, $2002.178 \mathrm{c}$.

15. Василенко В.Н. Экологические конфликты общества как предмет социологии и социальной экологии. Соииологические исследования. 1998. № 3. С. 73-79.

17. Дубовик О.Л. Экологические конфликты. Экологическое право. 2005. № 2. С. 3-14. 


\section{Анотація}

Ярелак З. В. Соціальна природа еколого-правового конфлікту. - Стаття.

У статті проаналізовано різні підходи до розуміння сутнісних характеристик екологічних конфліктів та зроблено висновок, що широкий спектр пропонованих концепцій не сприяє уніфікації змістовних характеристик екологічних конфліктів та зумовлює складність їх вивчення. Поліфункціональність категоріі конфлікту як основоположного поняття для екологічного конфлікту зумовлює складність визначення поняття та неоднозначне розуміння його сутнісних характеристик. Базовою категорією, яка здатна бути основою дефініції правового конфлікту та грунтуватися на сутнісних характеристиках зазначеного явища, повинен бути соціальний конфлікт як специфічний стан суспільних відносин, особливостями якого є наявність соціальних протиріч між учасниками конфліктних відносин.

На підставі запропонованого уніфікованого підходу до розуміння сутнісних характеристик конфлікту проведено дослідження екологічного конфлікту та його ідентифікацію як специфічного соціально-правового явища - еколого-правового конфлікту. Запропоновано дослідження проблематики екологічних конфліктів проводити на основі системного аналізу із застосуванням дедуктивного методу аналізу шляхом виокремлення загальних характеристик соціального конфлікту, їх конкретизації в соціально-екологічному конфлікті та деталізації у сфері правового регулювання. Доведено, що екологічним конфліктам притаманні сутнісні характеристики та механізм розвитку соціального конфлікту, а з іншого боку - вони володіють специфічними властивостями: відображають зміст процесів життєдіяльності людини в існуючих природних умовах та характеризують певний стан соціозв'язків у системі «суспільство - природа», тобто мають екологічний характер. Водночас ці відносини, отримуючи правову регламентацію, набувають форм конфлікту юридичного. На основі цього обгрунтовано думку, що еколого-правовий конфлікт необхідно досліджувати на основі нерозривної єдності його соціальної основи із правовим змістом. Зроблено висновок, що родові ознаки соціально-екологічного конфлікту у процесі юридизації трансформуються у ознаки правового характеру та набувають юридичного значення в екологічному конфлікті.
Ключові слова: конфлікт, соціальний конфлікт, юридизація, юридичний конфлікт, еколого-правовий конфлікт.

\section{Summary}

Yaremak $Z$. V. Social nature of legal enviromental conflict. - Article.

The article is analyzed different approaches to understanding the essential characteristics of environmental conflicts and made the conclusion that a wide range of proposed concepts do not contribute unification of meaningful attributes of environmental conflicts and determines to the complexity of their study. Due to the multi-functionality of the category of conflict as the underlying notion for environmental conflict, there is difficulty in defining it and ambiguity in understanding its nature. The basic category, which can be the basis for the definition of legal conflict, and based on the essential characteristics of this phenomenon, should be social conflict as a specific state of social relations, characterized by the existence of social contradictions between the parties involved in a conflict.

On the basis of proposed unified approach to understanding the essential characteristics of the conflict was conducted the research of environmental conflict and its identification as a specific socio-legal phenomenon - the environmental legal conflict.

The research of problems of the ecological conflicts suggested to carry out on the basis of system analysis with using a deductive method of analysis by outlining the general characteristics of social conflict, their concretization in a social-environmental conflict and detail in the field of legal regulation. It is proved that environmental conflicts inherent characteristics and mechanism of development of social conflict and on the other hand, they have specific properties that reflect the content of human life processes in the existing natural conditions and characterize a certain state of social ties in the system "Society - nature" that are environmentally friendly. At the same time, this relationship receiving legal regulation that take the form of a legal conflict. Based on this reasoned opinion that environmental-legal conflict should be investigated on the basis of the unbroken unity of its social base with its legal content. In conclusion, generic signs of social conflict in the process of juridization, are transformed in a legal signs and acquire a legal value in environmental conflict.

Key words: conflict, social conflict, juridization, legal conflict, legal environmental conflict. 